The influence of hydrogen sulfide on wheatgrass (Triticum aestivum L.) de- etiolation

Utjecaj sumporovodika na deetiolaciju pšenične trave (Triticum cestivum L.)

Kristić, M., Lisjak, M., Špoljarević, M., Teklić, T., Grubišić, S., Rebekić, A.

Poljoprivreda/Agriculture

ISSN: $1848-8080$ (Online)

ISSN: 1330-7142 (Print)

https://doi.org/10.18047/poljo.26.2.3

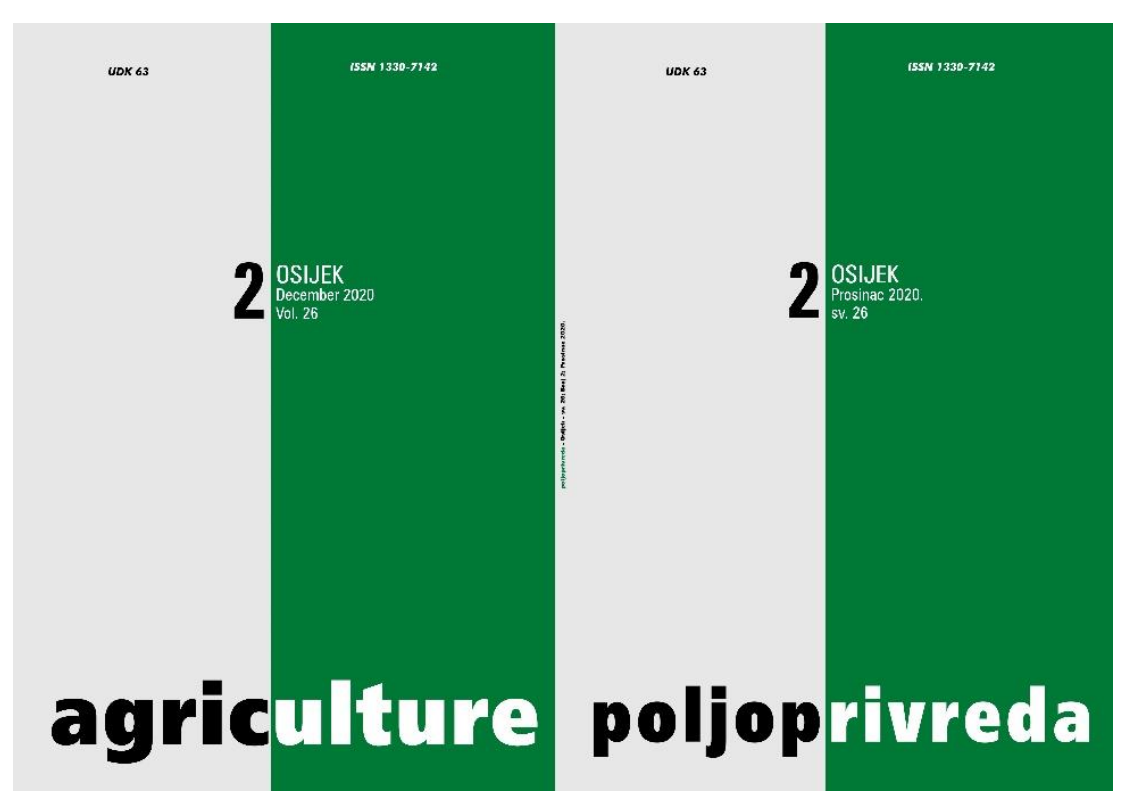

Fakultet agrobiotehničkih znanosti Osijek, Poljoprivredni institut Osijek

Faculty of Agrobiotechnical Sciences Osijek, Agricultural Institute Osijek 
ISSN 1330-7142

$U D K=581.131: 633.1$

https://doi.org/10.18047/poljo.26.2.3

\title{
THE INFLUENCE OF HYDROGEN SULFIDE ON WHEATGRASS (Triticum æstivum L.) DE-ETIOLATION
}

Kristić, M., Lisjak, M., Špoljarević, M., Teklić, T., Grubišić, S., Rebekić, A.

Original scientific paper

Izvorni znanstveni članak

\begin{abstract}
SUMMARY
Hydrogen sulfide $\left(\mathrm{H}_{2} \mathrm{~S}\right)$ is involved in many physiological processes and responses to the abiotic types of stress. The aim of the study was to determine the effect of sodium hydrogen sulfide (NaHS) and the time of application on the physiological properties of etiolated wheatgrass plants. Two genotypes of wheatgrass were grown under controlled conditions for five days without light and then with a 12-hour photoperiod, watered for three consecutive days with 100, 200, and 500 mM NaHS solutions. The plants were watered in three variants, 7-9, 10-12, and 13-15 days after sowing, respectively. The highest content of phenols, flavonoids, and hydrogen peroxide was found in wheatgrass plants watered with $100 \mathrm{mM}$ of NaHS solution. The highest proline content and lipid peroxidation levels were found in the plants at $500 \mathrm{mM}$ of NaHS solution. Also, the significant influence of the watering period on the examined physiological parameters was determined. The results show that $\mathrm{H}_{2} \mathrm{~S}$ significantly affects the de-etiolation process and concentration of physiologically active compounds in wheatgrass plants.
\end{abstract}

Keywords: NaHS, light stress, antioxidant activity, total phenolics, total flavonoids, DPPH

\section{INTRODUCTION}

It is known that wheatgrass, i.e., the young shoots of wheat (Triticum aestivum L.) from the family Poaceae, is a rich source of vitamins and minerals and has a high antioxidant effect, as well as a high concentration of chlorophyll, flavonoids, and amino acids. Precisely, wheatgrass is used in the prevention and treatment of chronic diseases because of the aforementioned properties (Rana et al., 2011; Singh et al., 2012; Chauhan, 2014; Payal et al., 2015), for it helps in the treatment of diabetes (Thammana et al., 2016) and cancer (Aydos et al., 2011; Tandon et al., 2011; Gore et al., 2017), has an anti-allergic effect (Padalia et al., 2010), it diminishes menopausal symptoms in women (Kumar and lyer, 2017), helps treat thalassemia (Desai et al., 2008), and demonstrates many other impacts.
The stress stimulates the formation of reactive oxygen species (ROS), resulting in the occurrence of oxidative stress in cells. The plants have antioxidant mechanisms to remove the excessive ROS, thus preventing the cell damage. Over the centuries, $\mathrm{H}_{2} \mathrm{~S}$ has been exclusively known for its toxicity and environmental hazards (Wang, 2012), but today it emerges as an important signaling molecule (Hancock et al., 2011; Li et al., 2016; Zhang, 2016), participating in the seed germination, plant growth, and development, as well as in the acquisition of stress tolerance, including a crossadaptation in plants (Li et al., 2016). The protective role

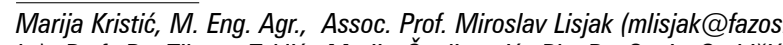
hr), Prof. Dr. Tihana Teklić, Marija Špoljarević, Ph. D., Sanja Grubišić, M. Eng. Agr., Assoc. Prof. Andrijana Rebekić - Josip Juraj Strossmayer University of Osijek, Faculty of Agrobiotechnical Sciences Osijek, Vladimira Preloga 1, 31000 Osijek, Croatia 
of hydrogen sulfide in the osmotic (Zhang et al., 2010), drought (Kolupaev et al. 2019a; Batista et al., 2020), heat (Min et al., 2016), and heavy metal stress (Rizwan et al., 2019; Zanganeh et al., 2019; Kaya et al., 2020) has been confirmed. So far, only a few studies have been conducted to examine the effects of hydrogen sulfide in the plants exposed to an excessive photon flux (Joshi et al., 2020; Liu et al., 2019). Fan et al. (2014) concluded that the protective effect of $\mathrm{H}_{2} \mathrm{~S}$ in plants exposed to the light stress depends on its concentration.

This study aimed to determine the influence of different $\mathrm{H}_{2} \mathrm{~S}$ concentrations and time of application on the physiological response of etiolated wheatgrass seedlings.

\section{MATERIAL AND METHODS}

\section{Plant material}

The research was conducted on two varieties of wheat, the French Renan and the Italian Libellula, from the year 2013-14, provided by the Faculty of Agrobiotechnical Sciences Osijek within the project entitled Creating Wheat for the Future: The Search for the New Genes from the Existing Sources, financed by the Croatian Science Foundation (HRZZ). The wheatgrass varieties were chosen based on the level of total antioxidative activity, evaluated in the preliminary research within the project entitled Genotypic Specificity of Wheatgrass (Triticum æstivum L.) HighNutrient Supplement. The Renan variety belongs to the group with the highest total antioxidant activity, while the Libellula belongs to the group with the lowest antioxidant activity.

\section{Growing of wheatgrass}

The wheat seeds were washed a few times using the deionized water and sown into the substrate in plastic containers. To induce the etiolation of seedlings, in the first five days the plants were grown in the darkness under the fully controlled conditions in the growth chamber, with a relative humidity amounting to $65 \%$ and at a constant air temperature amounting to $20^{\circ} \mathrm{C}$. From the sixth day after sowing, a photoperiod was set up at 12 hours. The plants were watered for three consecutive days (7-9, 10-12, and 13-15 days after sowing) with 30 $\mathrm{mL}$ of 100,200 , and $500 \mathrm{mM}$ NaHS solutions. The control was watered with the same amount of tap water. On the fifteenth day, the plants were cut off two $\mathrm{cm}$ above the ground, the plant material was collected and stored at $-80^{\circ} \mathrm{C}$ for further analysis after grinding in a mortar, and pestled with liquid nitrogen for further analysis. Two hundred seeds per replication were germinated, and the experiment was set up in four replicates.

The analysis of chloroplast pigment content, total phenols, and flavonoids content, ascorbic acid content, free proline content, hydrogen peroxide content, lipid peroxide level and free radical scavenging (DPPH) in wheatgrass

The content of chloroplast pigments (chlorophyll a, chlorophyll b, and carotenoids) was determined spectrophotometrically according to Holm and Wettstein (Holm, 1954; Wettstein, 1957). To detect the total content of phenols and flavonoids, $0.1 \mathrm{~g}$ of plant tissue was extracted with $1 \mathrm{~mL}$ of $70 \%$ ethanol for 48 hours at $-20^{\circ} \mathrm{C}$. The flavonoids were detected according to Ordonez et al. (2006). The phenols were detected according to Singleton and Rossi (1965). The concentration of blue complex with the Folin-Ciocalteu reagent was measured spectrophotometrically at $765 \mathrm{~nm}$ and compared with the absorbance of standard gallic acid (GA) solutions.

Ascorbic acid content was determined spectrophotometrically at $520 \mathrm{~nm}$ according to Roe and Kuether (1943), with some modifications. Wheatgrass was pulverized in the liquid nitrogen, and $0.3 \mathrm{~g}$ was extracted in the distilled water. By adding 13.3\% trichloroacetic acid and $2 \%$ dinitrophenylhydrazine-thiourea-copper sulfate reagent in the sample extracts, the ascorbic acid was transferred to a red bis-hydrazone during the incubation time amounting to three hours at $37^{\circ} \mathrm{C}$. After incubation, $65 \%$ of sulfuric acid was added. The calibration curve was delineated using the ascorbic acid solution as a standard.

A free proline content in $0.5 \mathrm{~g}$ of wheatgrass powder was determined according to Bates et al. (1973).

The concentration of hydrogen peroxide in $0.1 \mathrm{~g}$ of wheatgrass powder was determined by measuring the amount of titanium peroxide complex, which was deposited when the titanium (IV) oxysulphate sulfuric acid solution and $25 \%$ ammonium hydroxide solution were added to the plant extract (Mukherjee and Choudhouri, 1983). The absorbance was measured at $415 \mathrm{~nm}$ against a blank sample. The concentration of $\mathrm{H}_{2} \mathrm{O}_{2}$ was determined using an extinction coefficient amounting to $1.878 \mathrm{mM}^{-1} \mathrm{~cm}^{-1}$.

A lipid peroxidation was determined according to Heath and Packer (1968). The concentration of the lipid peroxidation product malondialdehyde (MDA) was calculated by using the molar extinction coefficient of $155 \mathrm{mM}^{-1} \mathrm{~cm}^{-1}$.

The wheatgrass' free radical-scavenging activity was measured using the method described by BrandWilliams et al. (1995). The measured wheatgrass' DPPH scavenging properties have been correlated to the amount of ascorbic acid with a known concentration.

\section{Statistical analysis}

The obtained data were statistically analyzed using the SAS Enterprise Guide 7.1 (SAS Institute Inc., Cary, NC, USA, 2017) software. The influence of the examined treatments (variety, solution concentration, and the 
time of solution application) on the investigated properties was determined by a factorial analysis of variance $(P \leq 0.05)$. The differences between the treatments were determined using Tukey's honestly significant difference test (HSD).

\section{RESULTS AND DISCUSSION}

In the absence of light, thylakoid membranes do not develop. The plants grown in the dark are elongated and etiolated (Lazarević and Poljak, 2019). Such plants are irresistible and susceptible to various abiotic and biotic stresses. Fan et al. (2014) investigated the effect of hydrogen sulfide on the orchid plants (Dendrobium officinale) grown under a high light stress. Watering the plants with $200 \mu \mathrm{M}$ of NaHS solution was circumstantiated to have exerted a positive effect on the level of maximum photochemical quantum yield of PSII. On the contrary, Liu et al. (2019) confirmed a positive effect of different concentrations of NaHS solutions on the reed wig plants (Festuca arundinacea Schreb.) grown in the low-light conditions. In the leaves of plants grown at the low light and treated with the NaHS solutions, a significant increase of chloroplast pigments was found. In our experiment, according to the $\mathrm{F}$ test, the content of chlorophyll a and chlorophyll b was under the influence of variety, watering term, NaHS solution and all their interactions (Table 1). The strongest effect on chlorophyll a, total chlorophyll, and carotenoids content was found in the NaHS treatment, compared to the effects of variety and the watering term. Chlorophyll $b$ was under the strongest influence of the variety, which oppositely has not exerted a significant effect on the content of carotenoids (Table 1).

Table 1. The significance of the effect of variety, watering term, NaHS solution, and their interactions on the content of chlorophyll a (Chl a), chlorophyll b (Chl b), total chlorophyll (Chl a +b) and carotenoids (Car) ( $\mathrm{mg} \mathrm{g}^{-1} \mathrm{FW}$ ) in the wheatgrass leaves. ANOVA, $\mathrm{F}$ test

Tablica 1. Značajnost utjecaja sorte, termina zalijevanja, otopine NaHS i njihovih interakcija na sadržaj klorofila a (Chl a), klorofila $b(C h l ~ b)$, ukupnih klorofila (Chl $a+b) i$ karotenoida (Car) $\left(\mathrm{mg} \mathrm{g}^{-1} \mathrm{FW}\right)$ u listu pšenične trave. ANOVA, $F$ test

\begin{tabular}{|c|c|c|c|c|c|c|c|c|}
\hline & \multicolumn{2}{|c|}{ Chl a } & \multicolumn{2}{|c|}{ Chl b } & \multicolumn{2}{|c|}{ Chl $a+b$} & \multicolumn{2}{|c|}{ Car } \\
\hline & F value & $\operatorname{Pr}>\mathrm{F}$ & $F$ value & $\operatorname{Pr}>\mathrm{F}$ & F value & $\operatorname{Pr}>\mathrm{F}$ & F value & $\operatorname{Pr}>\mathrm{F}$ \\
\hline Variety / Sorta & 8.29 & 0.0052 & 39.39 & $<.0001$ & 13.36 & 0.0005 & 1.97 & 0.1643 \\
\hline $\begin{array}{l}\text { Watering term } \\
\text { Termin zalijevanja }\end{array}$ & 9.46 & 0.0002 & 7.02 & 0.0016 & 8.74 & 0.0004 & 4.78 & 0.0113 \\
\hline Solution / Otopina & 24.20 & $<.0001$ & 15.42 & $<.0001$ & 22.22 & $<.0001$ & 12.62 & $<.0001$ \\
\hline $\begin{array}{l}\text { Variety*watering term } \\
\text { Sorta*termin zalijevanja }\end{array}$ & 6.95 & 0.0017 & 4.08 & 0.021 & 6.23 & 0.0032 & 1.50 & 0.2295 \\
\hline $\begin{array}{l}\text { Variety* } \text { solution } \\
\text { Sorta }{ }^{*} \text { otopina }\end{array}$ & 5.01 & 0.0033 & 4.90 & 0.0037 & 5.02 & 0.0032 & 2.20 & 0.0949 \\
\hline $\begin{array}{l}\text { Watering term* solution } \\
\text { Termin zalijevanja*otopina }\end{array}$ & 9.32 & $<.0001$ & 8.98 & $<.0001$ & 9.28 & $<.0001$ & 9.03 & $<.0001$ \\
\hline $\begin{array}{l}\text { Variety* watering term* }{ }^{*} \text { solution } \\
\text { Sorta*termin zalijevanja*otopina }\end{array}$ & 4.27 & 0.001 & 3.75 & 0.0027 & 4.17 & 0.0012 & 1.70 & 0.1325 \\
\hline
\end{tabular}

The variety Libellula, watered between the seventh and the ninth and between the tenth and the twelwth day, respectively, has had the lowest chlorophyll content at $500 \mathrm{mM}$ of NaHS solution, while between the thirteenth and the fifteenth day there were no significant differences found between the applied NaHS solutions (Table 2). The Renan variety, watered with $500 \mathrm{mM}$ of NaHS solution, showed the lowest content of total chlorophyl 1 between the seventh and the ninth day. In general, a $500 \mathrm{mM}$ NaHS solution, applied between the seventh and the nineth day, has significantly decreased the content of chlorophylls, whereas the Renan variety was found to be more susceptible, as compared to the Libellula. In average for both cultivars, the content of carotenoids in the plants watered in the first watering period was the lowest at $500 \mathrm{mM}$ of NaHS solution, while a significant increase was found in the two later watering periods (Table 2). 
Table 2. The Influence of wheatgrass variety (Libellula, Renan), watering term (seventh to nineth, tenth to twelwth, and thirteenth to fifteenth day after sowing, respectively), and the concentration of NaHS solution (control, 100, 200, and $500 \mathrm{mM}$ NaHS) on the content of chlorophyll a (Chl a), chlorophyll b (Chl b), total chlorophyll (Chl a $+b)$ and carotenoids (Car) $\left(\mathrm{mg} \mathrm{g}^{-1} \mathrm{FW}\right)$ in the wheatgrass leaves. The data are an average of four replicates; Tukey's HSD test

Tablica 2. Utjecaj sorte pšenične trave (Libellula, Renan), termina zalijevanja (7. - 9., 10. - 12., 13. - 15. dan nakon sjetve) i koncentracije otopine NaHS (kontrola, 100, 200 i 500 mM NaHS) na sadržaj klorofila a (Chl a), klorofila b (Chl b), ukupnih klorofila (Chl $\mathrm{a}+b)$ i karotenoida (Car) ( $\left.\mathrm{mg} \mathrm{g}^{-1} \mathrm{FW}\right)$ u listu pšenične trave. Podatci su prosjek četiriju ponavljanja; Tukey HSD test

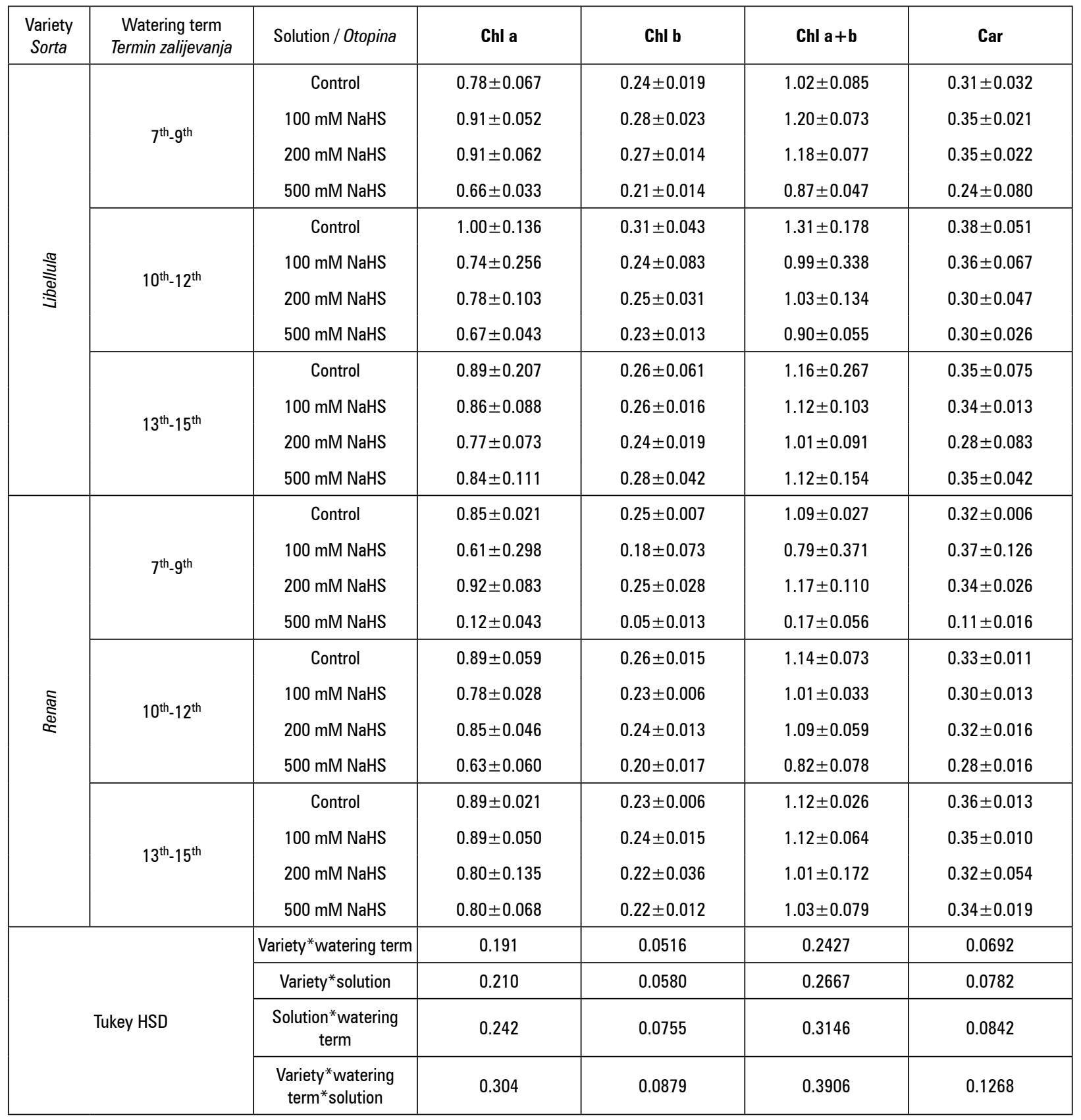

According to the $F$ test, the total phenols and flavonoids were most significantly influenced by the wheatgrass variety (Table 3 ). All the interactions have significantly affected the content of flavonoids. In both examined cultivars, watered with $100 \mathrm{mM}$ of an NaHS solution between the tenth and the twelwth day, a significant increase in the content of flavonoids was detected (Table 4). On average for all the NaHS solutions applied, a wheatgrass of the Renan variety, watered between the seventh and the nineth day and between the thirteenth and the fifteenth day, respectively, showed a significant increase in the total 
flavonoid content. Furthermore, in the Renan variety, watered with $100 \mathrm{mM}$ of NaHS between the tenth and the twelwth day, the highest flavonoid content was followed by the lowest level of lipid peroxidation (Table 4). Kolupaev et al. (2019b) stated that the influence of hydrogen sulfide on the flavonoid content is still insufficiently investigated; however, several previous studies confirmed a positive influence of hydrogen sulfide on the content of biological compounds. It is hypothesized that the flavonoids may be among the leading mechanisms concerning a plant's stress resistence under the influence of hydrogen sulfide.

The content of ascorbic acid and free proline was significantly affected by all applied treatments and their interactions (Table 3). The watering term had the most significant effect on the hydrogen peroxide content, while a total antioxidant activity was significantly influenced by the variety.

Table 3. The significance of variety effect, watering day, NaHS solution, and their interactions on the total content

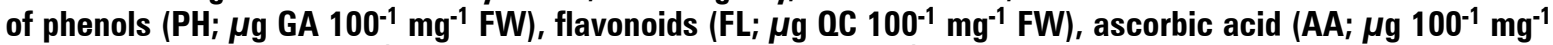
FW), proline (PRO; $\mu \mathrm{mol} \mathrm{g}^{-1} \mathrm{FW}$ ), hydrogen peroxide (HP nmol $\mathrm{g}^{-1} \mathrm{FW}$ ), lipid peroxidation levels (MDA; nmol MDA $\mathrm{g}^{-1} \mathrm{FW}$ ) and total antioxidant activity (DPPH; $\mathrm{mg}$ IC $50 \%$ ) in the wheatgrass leaves. ANOVA, $\mathrm{F}$ test

Tablica 3. Značajnost utjecaja sorte, dana zalijevanja, otopine NaHS i njihovih interakcija na ukupni sadržaj fenola (PH; $\mu g$ GA $100^{-1} \mathrm{mg}^{-1}$ Sv.T.), flavonoida (FL; $\mu$ OC $100^{-1} \mathrm{mg}^{-1}$ Sv.T.), askorbinske kiseline (AA; $\mu \mathrm{g} 100^{-1} \mathrm{mg}^{-1}$ Sv.T.), prolina (PRO; $\mu$ mol $g^{-1}$ Sv.T.), vodikovoga peroksida (HP nmol $g^{-1}$ Sv.T.), razinu lipidne peroksidacije (MDA; nmol MDA $g^{-1}$ Sv.T.) i ukupnu antioksidativnu aktivnost (DPPH; $m g$ IC 50\%) u listu pšenične trave. ANOVA, F test

\begin{tabular}{|c|c|c|c|c|c|c|c|c|c|c|c|c|c|c|}
\hline & \multicolumn{2}{|c|}{ PH } & \multicolumn{2}{|c|}{ FL } & \multicolumn{2}{|c|}{ AA } & \multicolumn{2}{|c|}{ PRO } & \multicolumn{2}{|c|}{ HP } & \multicolumn{2}{|c|}{ MDA } & \multicolumn{2}{|c|}{ DPPH } \\
\hline & F value & $\operatorname{Pr}>\mathrm{F}$ & $F$ value & $\operatorname{Pr}>\mathrm{F}$ & F value & $\mathrm{Pr}>\mathrm{F}$ & $F$ value & $\operatorname{Pr}>\mathrm{F}$ & F value & $\mathrm{Pr}>\mathrm{F}$ & $F$ value & $\operatorname{Pr}>\mathrm{F}$ & $F$ value & $\operatorname{Pr}>\mathrm{F}$ \\
\hline Variety / Sorta & 48.8 & $<.0001$ & 43.69 & $<.0001$ & 21.61 & $<.0001$ & 12.94 & 0.0006 & 10.34 & 0.0002 & 1.1 & 0.2986 & 125.72 & $<.0001$ \\
\hline $\begin{array}{l}\text { Watering term } \\
\text { Termin zalijevanja }\end{array}$ & 4.94 & 0.0097 & 0.66 & 0.5175 & 4.62 & 0.0013 & 29.85 & $<.0001$ & 121.31 & $<.0001$ & 6.56 & 0.0024 & 1.66 & 0.1974 \\
\hline Solution / Otopina & 2.95 & 0.0385 & 6.69 & 0.0005 & 17.05 & $<.0001$ & 32.28 & $<.0001$ & 3.09 & 0.0325 & 35.49 & $<.0001$ & 3.11 & 0.0315 \\
\hline $\begin{array}{l}\text { Variety* watering } \\
\text { term } \\
\text { Sorta * termin } \\
\text { zalijevanja }\end{array}$ & 2.42 & 0.0957 & 9.36 & 0.0002 & 5.98 & 0.004 & 15.6 & $<.0001$ & 134.47 & $<.0001$ & 13.64 & $<.0001$ & 0.71 & 0.4929 \\
\hline $\begin{array}{l}\text { Variety*solution } \\
\text { Sorta*otopina }\end{array}$ & 0.03 & 0.9941 & 3 & 0.0362 & 8.56 & $<.0001$ & 12.96 & $<.0001$ & 2.56 & 0.062 & 4.62 & 0.0052 & 0.93 & 0.4309 \\
\hline $\begin{array}{l}\text { Watering } \\
\text { term*solution } \\
\text { Termin zalijevanja* } \\
\text { Otopina }\end{array}$ & 0.67 & 0.6713 & 2.57 & 0.0258 & 2.73 & 0.0192 & 15.05 & $<.0001$ & 1.85 & 0.1007 & 4.99 & 0.0003 & 3.45 & 0.0047 \\
\hline $\begin{array}{l}\text { Variety* watering } \\
\text { term* solution } \\
\text { Sorta*termin } \\
\text { zalijevanja* } \\
\text { otopina }\end{array}$ & 1.41 & 0.2215 & 4.34 & 0.0009 & 1.31 & 0.2636 & 14.49 & $<.0001$ & 2.53 & 0.0279 & 6.66 & $<.0001$ & 3.66 & 0.0031 \\
\hline
\end{tabular}

On average, the content of flavonoids, vitamin $\mathrm{C}$, and antioxidant activity for all the watering variants and all NaHS solutions were significantly higher in the Renan variety. Zhang et al. (2013) reported the synergistic interactions among the ascorbic acid, ferulic acid, and flavonoids in wheat seedlings, followed by an increase of total antioxidant activity measured by a DPPH and ABTS method. Their research showed that an antioxidant activity depends on the concentration and ratio of the aforementioned compounds, whereas the highest influence was that of the flavonoids.

On average, for both cultivars and the watering terms, the proline content and the lipid peroxidation lev- els were significantly higher in the plants watered with $500 \mathrm{mM}$ NaHS. Also, on average for all $\mathrm{H}_{2} \mathrm{~S}$ treatments tested, in the Renan wheatgrass, watered between the thirteenth and the fifteenth day, and a higher content of proline was followed by a lower level of lipid peroxidation (Table 4).

Kolupaev et al. (2019a) studied the effect of hydrogen sulfide on the antioxidant status of young winter wheat plants (Triticum æstivum L. Doskonala) due to drought stress. A pretreatment with the NaHS prevented the accumulation of hydrogen peroxide and lipid peroxidation caused by a drought stress. The NaHS treatment also resulted in a significant increase of proline, anthocyanins, and flavonoids content. 
Table 4. The influence of wheatgrass variety (Libellula, Renan), watering day (seventh to nineth, tenth to twelwth, and thirteenth to fifteenth day after sowing, respectively) and the concentration of an NaHS solution (control, 100, 200 and $500 \mathrm{mM} \mathrm{NaHS}$ ) on a total content of phenols (PH; $\mu \mathrm{g} \mathrm{GA} 100^{-1} \mathrm{mg}^{-1} \mathrm{FW}$ ), flavonoids (FL; $\mu \mathrm{g} \mathrm{OC} \mathrm{100^{-1 }}$ $\mathrm{mg}^{-1} \mathrm{FW}$ ), ascorbic acid (AA; $\mu \mathrm{g} 100^{-1} \mathrm{mg}^{-1} \mathrm{FW}$ ), proline (PRO; $\mu$ mol g ${ }^{-1} \mathrm{FW}$ ), hydrogen peroxide (HP $\mathrm{nmol} \mathrm{g}{ }^{-1} \mathrm{FW}$ ), and lipid peroxidation levels (MDA; nmol MDA $\mathrm{g}^{-1} \mathrm{FW}$ ) and a total antioxidant activity (DPPH; $\mathrm{mg}$ IC $50 \%$ ) in the wheatgrass leaves. The data are an average of four replicates; Tukey HSD test

Tablica 4. Utjecaj sorte pšenične trave (Libellula, Renan), dana zalijevanja (7. - 9., 10. - 12., 13. - 15. dan nakon sjetve) i koncentracije otopine NaHS (kontrola, 100, 200 i $500 \mathrm{mM}$ NaHS) na ukupni sadržaj fenola (PH; $\mu g$ GA 100-1 $\mathrm{mg}^{-1} \mathrm{~Sv} . \mathrm{T}$.), flavonoida (FL; $\mu$ OC $100^{-1} \mathrm{mg}^{-1}$ Sv.T.), askorbinske kiseline (AA; $\mu \mathrm{g} 100^{-1} \mathrm{mg}^{-1}$ Sv. T.), prolina (PRO; $\mu \mathrm{mol} \mathrm{g}^{-1}$ Sv. T.), vodikovoga peroksida (HP nmol $g^{-1}$ Sv. T.), razinu lipidne peroksidacije (MDA; nmol MDA $g^{-1}$ Sv.T.) i ukupnu antioksidativnu aktivnost (DPPH; mg IC 50\%) u listu pšenične trave. Podatci su prosjek četiriju ponavljanja; Tukey HSD test

\begin{tabular}{|c|c|c|c|c|c|c|c|c|c|}
\hline $\begin{array}{l}\text { Variety } \\
\text { Sorta }\end{array}$ & $\begin{array}{l}\text { Watering } \\
\text { term } \\
\text { Termin } \\
\text { zalijevanja }\end{array}$ & $\begin{array}{l}\text { Solution } \\
\text { Otopina }\end{array}$ & PH & $\mathbf{F L}$ & AA & PRO & HP & MDA & DPPH \\
\hline \multirow{12}{*}{$\begin{array}{l}\frac{0}{5} \\
\frac{\bar{E}}{0} \\
\stackrel{\Xi}{\Xi}\end{array}$} & \multirow{4}{*}{$7^{\text {th }}-9^{\text {th }}$} & Control & $217.78 \pm 50.85$ & $104.48 \pm 13.19$ & $0.80 \pm 0.098$ & $0.57 \pm 0.170$ & $9.31 \pm 1.10$ & $27.43 \pm 1.20$ & $19.15 \pm 6.54$ \\
\hline & & $100 \mathrm{mM}$ NaHS & $218.73 \pm 16.35$ & $98.84 \pm 8.65$ & $0.86 \pm 0.113$ & $0.69 \pm 0.197$ & $8.48 \pm 1.22$ & $23.99 \pm 3.86$ & $17.85 \pm 2.85$ \\
\hline & & $200 \mathrm{mM}$ NaHS & $207.48 \pm 13.37$ & $92.23 \pm 5.50$ & $0.93 \pm 0.118$ & $0.56 \pm 0.279$ & $7.83 \pm 0.43$ & $23.11 \pm 3.17$ & $20.70 \pm 3.47$ \\
\hline & & $500 \mathrm{mM}$ NaHS & $241.77 \pm 7.89$ & $101.29 \pm 2.46$ & $0.78 \pm 0.064$ & $1.04 \pm 0.164$ & $7.87 \pm 0.61$ & $33.05 \pm 2.75$ & $18.81 \pm 4.22$ \\
\hline & \multirow{4}{*}{$10^{\text {th }}-12^{\text {th }}$} & Control & $192.83 \pm 83.94$ & $128.44 \pm 14.50$ & $0.74 \pm 0.114$ & $0.27 \pm 0.033$ & $11.75 \pm 1.38$ & $25.31 \pm 0.63$ & $14.65 \pm 0.22$ \\
\hline & & $100 \mathrm{mM}$ NaHS & $283.21 \pm 124.08$ & $165.39 \pm 59.59$ & $0.84 \pm 0.156$ & $0.56 \pm 0.033$ & $7.40 \pm 4.21$ & $31.09 \pm 12.64$ & $10.83 \pm 4.89$ \\
\hline & & $200 \mathrm{mM}$ NaHS & $199.38 \pm 10.83$ & $91.69 \pm 7.03$ & $0.75 \pm 0.104$ & $0.45 \pm 0.061$ & $7.72 \pm 0.98$ & $27.10 \pm 1.54$ & $18.08 \pm 1.96$ \\
\hline & & $500 \mathrm{mM}$ NaHS & $242.28 \pm 30.21$ & $104.98 \pm 6.49$ & $0.71 \pm 0.061$ & $0.98 \pm 0.380$ & $9.21 \pm 0.81$ & $35.79 \pm 4.08$ & $19.50 \pm 1.06$ \\
\hline & \multirow{4}{*}{$13^{\text {th }}-15^{\text {th }}$} & Control & $191.60 \pm 14.24$ & $100.65 \pm 12.34$ & $0.63 \pm 0.112$ & $0.27 \pm 0.028$ & $7.37 \pm 2.21$ & $23.23 \pm 2.21$ & $22.12 \pm 8,40$ \\
\hline & & $100 \mathrm{mM}$ NaHS & $177.41 \pm 63.18$ & $112.93 \pm 12.93$ & $0.75 \pm 0.063$ & $0.34 \pm 0.096$ & $8.68 \pm 0.74$ & $25.74 \pm 4.49$ & $20.23 \pm 1.52$ \\
\hline & & $200 \mathrm{mM}$ NaHS & $149.50 \pm 89.43$ & $101.05 \pm 6.85$ & $0.76 \pm 0.042$ & $0.40 \pm 0.062$ & $8.54 \pm 0.37$ & $24.36 \pm 0.92$ & $21.27 \pm 6.62$ \\
\hline & & $500 \mathrm{mM}$ NaHS & $176.96 \pm 90.71$ & $127.09 \pm 17.44$ & $0.62 \pm 0.085$ & $0.60 \pm 0.043$ & $8.82 \pm 1.68$ & $34.58 \pm 6.15$ & $6.38 \pm 4.92$ \\
\hline \multirow{12}{*}{ 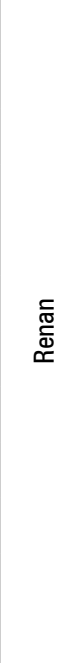 } & \multirow{4}{*}{$7^{\text {th }}-9^{\text {th }}$} & Control & $286.22 \pm 11.83$ & $167.59 \pm 9.09$ & $1.00 \pm 0.249$ & $0.33 \pm 0.121$ & $16.83 \pm 4.19$ & $22.07 \pm 2.30$ & $10.97 \pm 11.56$ \\
\hline & & $100 \mathrm{mM}$ NaHS & $391.21 \pm 152.38$ & $232.24 \pm 109.42$ & $0.71 \pm 0.214$ & $1.45 \pm 1.283$ & $21.05 \pm 1.20$ & $36.75 \pm 20.14$ & $11.12 \pm 8.61$ \\
\hline & & $200 \mathrm{mM}$ NaHS & $269.12 \pm 3.92$ & $164.05 \pm 5.06$ & $1.08 \pm 0.116$ & $0.21 \pm 0.17$ & $15.84 \pm 3.62$ & $15.20 \pm 1.55$ & $6.40 \pm 1.13$ \\
\hline & & $500 \mathrm{mM}$ NaHS & $311.16 \pm 52.50$ & $114.54 \pm 29.33$ & $0.56 \pm 0.039$ & $5.58 \pm 2.010$ & $18.43 \pm 1.98$ & $60.38 \pm 2.06$ & $2.04 \pm 1.56$ \\
\hline & \multirow{4}{*}{$10^{\text {th }}-12^{\text {th }}$} & Control & $274.59 \pm 10.83$ & $77.07 \pm 10.17$ & $0.97 \pm 0.083$ & $0.38 \pm 0.042$ & $5.84 \pm 0.53$ & $20.80 \pm 2.66$ & $5.48 \pm 3.54$ \\
\hline & & $100 \mathrm{mM}$ NaHS & $274.24 \pm 17.18$ & $161.88 \pm 4.29$ & $0.96 \pm 0.058$ & $0.35 \pm 0.053$ & $6.85 \pm 1.92$ & $20.00 \pm 1.40$ & $6.61 \pm 0.26$ \\
\hline & & $200 \mathrm{mM}$ NaHS & $254.44 \pm 3.39$ & $149.84 \pm 3.64$ & $0.96 \pm 0.107$ & $0.32 \pm 0.020$ & $4.45 \pm 0.43$ & $17.48 \pm 2.58$ & $7.96 \pm 0.69$ \\
\hline & & $500 \mathrm{mM}$ NaHS & $292.11 \pm 14.81$ & $128.88 \pm 39.72$ & $0.75 \pm 0.042$ & $0.81 \pm 0.081$ & $5.00 \pm 0.58$ & $29.41 \pm 2.12$ & $7.56 \pm 2.03$ \\
\hline & \multirow{4}{*}{$13^{\text {th }}-15^{\text {th }}$} & Control & $283.82 \pm 5.39$ & $169.77 \pm 8.10$ & $0.94 \pm 0.045$ & $0.33 \pm 0.030$ & $6.69 \pm 0.51$ & $22.26 \pm 2.73$ & $6.09 \pm 0.72$ \\
\hline & & $100 \mathrm{mM}$ NaHS & $266.57 \pm 3.80$ & $150.96 \pm 2.78$ & $0.85 \pm 0.052$ & $0.34 \pm 0.019$ & $5.24 \pm 0.84$ & $23.14 \pm 6.10$ & $6.41 \pm 2.87$ \\
\hline & & $200 \mathrm{mM}$ NaHS & $264.72 \pm 19.42$ & $147.9 \pm 13.02$ & $0.89 \pm 0.068$ & $0.45 \pm 0.033$ & $5.16 \pm 0.96$ & $23.28 \pm 2.15$ & $8.61 \pm 0.98$ \\
\hline & & $500 \mathrm{mM}$ NaHS & $285.56 \pm 23.42$ & $141.44 \pm 34.06$ & $0.70 \pm 0.046$ & $0.60 \pm 0.031$ & $5.74 \pm 1.43$ & $29.49 \pm 1.55$ & $6.12 \pm 1.28$ \\
\hline \multirow{4}{*}{$\begin{array}{l}\overrightarrow{\vec{\theta}} \\
\text { 总 }\end{array}$} & \multicolumn{2}{|c|}{$\begin{array}{l}\text { Variety }{ }^{*} \text { watering term } \\
\text { sorta }{ }^{*} \text { termin zalijevanja }\end{array}$} & 58.539 & 38.207 & 0.1528 & 1.0694 & 2.0917 & 9.9315 & 5.5251 \\
\hline & \multicolumn{2}{|c|}{$\begin{array}{l}\text { Variety* solution } \\
\text { sorta*otopina }\end{array}$} & 75.124 & 46.048 & 0.1567 & 1.2517 & 5.9914 & 10.311 & 6.6764 \\
\hline & \multicolumn{2}{|c|}{$\begin{array}{l}\text { Watering term* solution } \\
\text { termin zalijevanja* } \\
\text { otopina }\end{array}$} & 118.57 & 70.404 & 0.2315 & 1.4327 & 6.3693 & 12.871 & 12.408 \\
\hline & \multicolumn{2}{|c|}{$\begin{array}{l}\text { Variety*watering } \\
\text { term* }{ }^{*} \text { solution } \\
\text { Sorta*termin zalijevanja* } \\
\text { otopina }\end{array}$} & 149.22 & 78.847 & 0.2862 & 1.343 & 4.8009 & 15.111 & 12.09 \\
\hline
\end{tabular}


In general, an increase in the content of free proline was followed by a higher level of lipid peroxidation in all the watering terms in the wheatgrass plants, which were watered with the highest concentration of an NaHS solution. In a water solution, NaHS will dissociate rapidly to generate a very short burst of $\mathrm{H}_{2} \mathrm{~S}$, which is a volatile compound and will evaporate quickly. On the other hand, the sodium ions remaining in the substrate after a $500 \mathrm{mM}$ NaHS application could cause an ionic stress, confirmed by the accumulation of an osmoprotective compound, proline.

\section{CONCLUSION}

The influence of the sodium hydrogen sulfide and the watering term on all the analyzed physiological properties of etiolated wheatgrass plants were established. The application of $500 \mathrm{mM}$ of an NaHS solution have exerted a negative impact on the tested parameters in both wheatgrass varieties. The negative effect was more pronounced in the first watering term, when the plants were still recovering from the etiolation after being grown in the darkness. According to the obtained results, the Renan variety seems to be more tolerant to the etiolation. The lower concentrations of the $\mathrm{H}_{2} \mathrm{~S}$ applied resulted in a higher accumulation of physiologically active compounds and, consequently, in a more efficient etiolation recovery, confirming a protective $\mathrm{H}_{2} \mathrm{~S}$ role.

\section{ACKNOWLEDGEMENT}

This research was funded by the Croatian Science Foundation as part of the UIP-2017-05-4292 project.

\section{REFERENCES}

1. Aydos, 0. S., Avci, A., Özkan, T., Karadağ, A., Gürleyik, E., Altinok, B., \& Sunguroğlu, A. (2011). Antiproliferative, apoptotic and antioxidant activities of wheatgrass (Triticum aestivum L.) extract on CML (K562) cell line. Turkish Journal of Medical Sciences, 41(4), 657-663.

2. Bates, L. S., Waldern, R. P., \& Teare, I. D. (1973). Rapid determination of free prolin for water stress studies. Plant and Soil, 39(1), 205-207.

3. Batista, P. F., Müller, C., Merchant, A., Fuentes, D., Silva-Filho, R. D. O., da Silva, F. B., \& Costa, A. C. (2020). Biochemical and physiological impacts of zinc sulphate, potassium phosphite and hydrogen sulphide in mitigating stress conditions in soybean. Physiologia plantarum, 168(2), 456-472.

https://doi.org/0.1111/ppl.13034

4. Brand-Williams, W., Cuvelier, M. E., \& Berset, C. (1995). Use of a free radical method to evaluate antioxidant activity, LWT - Food Science and Technology, 28(1), 25-30. https://doi.org/10.1016/S0023-6438(95)80008-5

5. Chauhan, M. (2014). A pilot study on wheat grass juice for its phytochemical, nutritional and therapeutic potential on chronic diseases. International Journal of Chemical Studies, 2(4), 27-34.
6. Desai, T. R., Solanki, J. K., Buch, P., \& Goyal, R. K. (2008). Triticum aestivum (Wheatgrass) formulation: an alternate treatment for the patients with thalassemia. Oriental Pharmacy and Experimental Medicine, 7(5), 466-476.

7. Fan, H., Guan, L., Li, T., Wu, Q., Wu, M., Cai, Y., \& Lin, Y. (2014). Hydrogen sulphide alleviates oxidative damage and enhances light energy transformation under high light for Dendrobium officinale. Scientia Horticulturae, 177, 47-52. http://dx.doi.org/10.1016/j.scienta.2014.07.034

8. Gore, R. D., Palaskar, S. J., \& Bartake, A. R. (2017). Wheatgrass: green blood can help to fight cancer. Journal of Clinical and Diagnostic Research: JCDR, $11(6), 40-42$. https://doi.org/10.7860/JCDR/2017/26316.10057

9. Hancock, J. T., Lisjak, M., Teklić, T., Wilson, I. D., \& Whiteman M. (2011). Hydrogen sulphide and signalling in plants. CAB Reviews: Perspectives in Agriculture, Veterinary Science, Nutrition and Natural Resources 6, 1-7. https://doi.org/10.1079/PAVSNNR20110012

10. Heath, R. L., \& Packer, L. (1968). Photoperoxidation in isolated chloroplasts. I-Kinetics and stoichiometry of fatty acid peroxidation. Archives of Biochemistry and Biophysics, 125(1), 189-198.

https://doi.org/10.1016/0003-9861(68)90654-1

11. Holm, G. (1954). Chlorophyll mutations in barley. Acta Agriculturae Scandinavica, 4(1), 457-461. https://doi.org/10.1080/00015125409439955

12. Joshi, N. C., Yadav, D., Ratner, K., Kamara, I., AvivSharon, E., Irihimovitch, V. \& Charuvi, D. (2020). Sodium hydrosulfide priming improves the response of photosynthesis to overnight frost and day high light in avocado (Persea americana Mill, cv. 'Hass'). Physiologia plantarum, 168(2), 394-405.

https://doi.org/10.1111/ppl.13023

13. Kaya, C., Ashraf, M., Alyemeni, M. N., \& Ahmad, P. (2020). Responses of nitric oxide and hydrogen sulfide in regulating oxidative defence system in wheat plants grown under cadmium stress. Physiologia plantarum 168(2), 345-360. https://doi.org/10.1111/ppl.13012

14. Kolupaev, Y. E., Firsova, E. N., Yastreb, T. O., Ryabchun N. I., \& Kirichenko V. V. (2019a). Effect of hydrogen sulfide donor on antioxidant state of wheat plants and their resistance to soil drought. Russian Journal of Plant Physiology, 66(1), 59-66. https://doi.org/10.1134/ S1021443719010084

15. Kolupaev, Y. E., Karpets, Y. V., \& Yastreb, T. O. (2019). Induction of wheat plant resistance to stressors by donors of nitric oxide and hydrogen sulfide. In Wheat Production in Changing Environments (pp. 521-556). Springer, Singapore. https://doi.org/10.1007/978-981-13-6883-7

16. Kumar, N., \& lyer, U. (2017). Impact of wheatgrass (Triticum aestivum L.) supplementation on atherogenic lipoproteins and menopausal symptoms in hyperlipidemic South Asian Women - A randomized controlled study. Journal of Dietary Supplements, 14(5), 503-513.

17. Lazarević, B. \& Poljak, M. (2019). Fiziologija bilja. Sveučilište u Zagrebu, Agronomski fakultet. 
18. Li, Z. G., Min, X., \& Zhou, Z. H. (2016). Hydrogen sulfide: a signal molecule in plant cross-adaptation. Frontiers in Plant Science, 7, 1621. https://doi.org/10.3389/fpls.2016.01621

19. Liu, Y. H., Zhang, X. H., Liu, B. W., Ao, B., Liu, O., Wen, S. Y., \& Xu, Y. F. (2019). Hydrogen sulfide regulates photosynthesis of tall fescue under low-light stress. Photosynthetica, 57(3), 714-723. https://doi.org/10.32615/ps.2019.094

20. Min, Y., Qin, B. P., Ping, Ma, X. I., Wang P., Li, M. I., Chen, L. I., Chen, L. T., Sun, A. 0., Wang, Z. I. \& Yin, Y. P. (2016). Foliar application of sodium hydrosulfide (NaHS), a hydrogen sulfide $\left(\mathrm{H}_{2} \mathrm{~S}\right)$ donor, can protect seedlings against heat stress in wheat (Triticum aestivum L.). Journal of Integrative Agriculture, 15(12), 27452758. https://doi.org/10.1016/S2095-3119(16)61358-8

21. Mukherjee, S.P., \& Choudhouri, M.A. (1983). Implications of water stress-induced changes in the levels of endogenous ascorbic acid and hydrogen peroxide in Vigna seedlings. Physiologia plantarum 58, 166-170.

22. Ordonez, A. A. L., Gomez, J. D., \& Vattuone, M. A. (2006). Antioxidant activities of Sechium edule (Jacq.) Swartz extracts. Food Chemistry, 97(3), 452458. https://doi.org/10.1016/j.foodchem.2005.05.024

23. Padalia, S., Drabu, S., Raheja, I., Gupta, A., \& Dhamija, M. (2010). Multitude potential of wheatgrass juice (Green Blood): an overview. Chronicles of Young Scientists, 1(2), 23-28.

24. Payal, C., Davinder, K., Gurlaganjeet, S. K., Gagan, S., Amit, C., \& Dhawan, R. K. (2015). Wheat grass: a review on pharmacognosy and pharmacological aspects. International Journal of Phytopharmacology, 6(2), 80-85.

25. Rana, S., Kamboj, J. K., \& Gandhi, V. (2011). Living life the natural way - wheatgrass and health. Functional Foods in Health and Disease, 1(11), 444-456. https://doi.org/10.31989/ffhd.v1i11.112

26. Rizwan, M., Mostofa, M. G., Ahmad, M. Z., Zhou, Y., Adeel, M., Mehmood, S., ... \& Ikram, M. (2019). Hydrogen sulfide enhances rice tolerance to nickel through the prevention of chloroplast damage and the improvement of nitrogen metabolism under excessive nickel. Plant Physiology and Biochemistry, 138, 100-111. https://doi.org/10.1016/j.plaphy.2019.02.023

27. Roe, H. J. \& Kuether, A. C. (1943). The Determination of ascorbic acid in whole blood and urine through the 2,4-dinitrophenylhydrazine derivative of dehydroascorbic acid. The Journal of Biological Chemistry, 147, 399407.

28. Singh, N., Verma, P., \& Pandey, B. R. (2012). Therapeutic potential of organic Triticum aestivum Linn. (wheat grass) in prevention and treatment of chronic diseases: an overview. International Journal of Pharmaceutical Sciences and Drug Research, 4(1), 10-14.

29. Singleton, V. L., \& Rossi, J. A. (1965). Colorimetry of total phenolics with phosphomolybdic-phosphotungstic acid reagents. American Journal of Enology and Viticulture, 16(3), 144-158.

30. Tandon, S., Arora, A., Singh, S., Monga, J., \& Arora, S. (2011). Antioxidant profiling of Triticum aestivum (wheatgrass) and its antiproliferative activity in MCF-7 breast cancer cell line. Journal of Pharmacy Research, 4(12), 4601-4604.

31. Thammana, M., Sreerangam, S., \& Nambaaru, S. (2016). A mini review on wheatgrass. Journal of Pharmacognosy and Phytochemistry, 4(3), 13-19.

32. Wang, R. (2012). Physiological implications of hydrogen sulfide: a whiff exploration that blossomed. Physiological Reviews 92, 791-896. https://doi.org/10.1152/physrev.00017.2011

33. Von Wettstein, D. (1957). Chlorophyll - Letale und der Submikroskopische Formwechsel der Plastiden. Experimental Cell Research, 12(3), 427-487. https://doi.org/10.1016/0014-4827(57)90165-9

34. Zhang, H., Wang, M. J., Hu, L. Y., Wang, S. H., Hu, K. D., Bao, L. J., \& Luo, J. P. (2010). Hydrogen sulfide promotes wheat seed germination under osmotic stress. Russian Journal of Plant Physiology, 57(4), 532-539. https://doi.org/10.1134/S1021443710040114

35. Zhang, H. (2016). Hydrogen sulfide in plant biology In Gasotransmitters in Plants (pp. 23-51). Springer, Cham. https://doi.org/10.1007/978-3-319-40713-5_2

36. Zhang, Z., Xiang, J., Zhou, L., \& Pu, B. (2013). Synergistic antioxidant activity of ferulic acid, ascorbic acid (Vitamin C) and flavonoids in wheat seeding. Journal of the Chinese Cereals and Oils Association, 28. 5-11+18

37. Zanganeh, R., Jamei, R., \& Rahmani, F. (2019). Role of salicylic acid and hydrogen sulfide in promoting lead stress tolerance and regulating free amino acid composition in Zea mays L. Acta Physiologiae plantarum, 41(6), 94-99. https://doi.org/10.1007/s11738-019-2892-z 


\section{UTJECAJ SUMPOROVODIKA \\ NA DEETIOLACIJU PŠENIČNE TRAVE (Triticum æstivum L.)}

\section{SAŽETAK}

Sumporovodik $\left(\mathrm{H}_{2} \mathrm{~S}\right)$ je uključen u velik broj fizioloških procesa $i$ reakcija na abiotske tipove stresa. Cilj istraživanja bio je utvrditi utjecaj natrijevog hidrogensulfida (NaHS) i vremena primjene na fiziološka svojstva etioliranih biljaka pšenične trave. Dva su genotipa pšenične trave uzgajana u kontroliranim uvjetima pet dana bez svjetlosti te nakon toga uz dvanaestosatni fotoperiod, zalijevane tri dana zaredom otopinama NaHS koncentracija 100, 200 i 500 mM. Varijante tretmana zalijevanja uz osvjetljenje bile su sedmoga do devetoga, desetoga do dvanaestoga te trinaestoga do petnaestoga dana nakon sjetve. Najveći sadržaj fenola, flavonoida te vodikova peroksida utvrđen je kod biljaka pšenične trave zalijevanih otopinom 100 mM NaHS. Najviši sadržaj prolina i lipidna peroksidacija utvrđeni su kod biljaka pri 500 mM NaHS. Također, utvrđen je i značajan utjecaj perioda zalijevanja na ispitivane fiziološke parametre. Rezultati pokazuju da $\mathrm{H}_{2} \mathrm{~S}$ značajno utječe na proces deetiolacije kod biljaka pšenične trave i sadržaj fiziološki aktivnih komponenata u pšeničnoj travi.

Ključne riječi: natrij hidrogen sulfid, svjetlosni stres, antioksidativna aktivnost, ukupni fenoli, ukupni flavonoidi, DPPH

(Received on September 10, 2020; accepted on October 23, 2020 - Primljeno 10. rujna 2020.; prihvaćeno 23. listopada 2020.) 